Primljen / Received: 26.2.2013.

Ispravljen / Corrected: 7.7.2013.

Prihvaćen / Accepted: 26.11.2013.

Dostupno online / Available online: 10.12.2013.

\section{Work cycle based scheduling}

Authors:

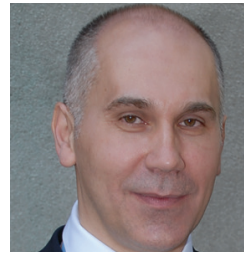

Dejan Marinković, PhD. CE University of Belgrad

Faculty of Civil Engineering dejan@grf.rs

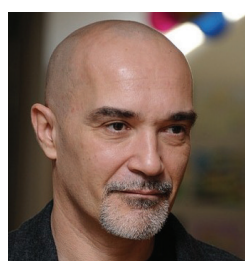

Assist.Prof. Zoran Stojadinović, PhD. CE University of Belgrad

Faculty of Civil Engineering joka@grf.bg.ac.rs

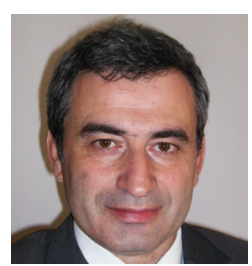

Assoc.Prof. Nenad Ivanišević, PhD. CE University of Belgrad

Faculty of Civil Engineering nesa@grf.bg.ac.rs

\section{Dejan Marinković, Zoran Stojadinović, Nenad Ivanišević}

\section{Work cycle based scheduling}

The paper proposes a new approach to short-term scheduling based on spatial and technological cycles, continuous crew flows and daily scheduling, named WCBS (Work Cycle Based Scheduling). Application of WCBS is shown on a case study of constructing seven multi-storey structures. It was concluded that WCBS helps overcome restrictions of existing approaches to micro scheduling (daily tasks and crew coordination), enhances the scheduling process and increases productivity of works.

\section{Key words:}

short-term schedules, workflow, work cycle, productivity

\section{Dejan Marinković, Zoran Stojadinović, Nenad Ivanišević}

Pregledni rad

\section{Dinamički planovi utemeljeni na ciklusima rada}

U radu se predlaže novi pristup kratkoročnom planiranju nazvan PCR (planovi po ciklusima rada), koji se temelji na prostornim i tehnološkim ciklusima, kontinuiranim radnim procesima grupa i dnevnom planiranju. Predloženi novi pristup planiranju ispitan je na primjeru izgradnje sedam višekatnih građevina. Zaključeno je kako se primjenom PCR-a može uspješno utjecati na to da se prevladaju ograničenja postojećih pristupa planiranju na mikrorazini (dnevni zadaci, uskladivanje radnih grupa), unaprijedi proces izrade planova i poboljša produktivnost radova.

Ključne riječi:

kratkoročni planovi, tok rada, ciklus rada, produktivnost

Übersichtsarbeit

\section{Dejan Marinković, Zoran Stojadinović, Nenad Ivanišević}

\section{Auf Arbeitszyklen basierte dynamische Planung}

In der vorliegenden Arbeit wird ein neues Verfahren kurzfristiger Planung vorgeschlagen, das sich AZBP (auf Arbeitszyklen basierte Planung) nennt und auf räumlichen und technologischen Zyklen, fliessendem Wechsel der Teammitglieder, sowie kontinuierlicher Tagesplanung beruht. Anwendungen sind am Beispiel der Erbauung sieben mehrstöckiger Gebäude dargestellt. Es ist festgestellt worden, dass Einschränkungen bestehender Vorgänge der Mikroplanung (tägliche Aufgaben and Teamkoordination) überwindet werden können, sowie der Planungsprozess verbessert und die Arbeitsproduktivität erhöht werden können.

Schlüsselwörter:

kurzfristige Planung, Arbeitsablauf, Arbeitszyklus, Produktivität 


\section{Introduction}

Research conducted on an international scale shows that over the past several decades, the productivity in civil engineering has not been following the productivity growth trends shown in other spheres of economy [1-6]. Thus, in the period from 1979 to 2005 , the fall in productivity in construction industry in the US amounted to $0.84 \%$ annually, while it amounted to 0.06 $\%$ annually in Germany and Japan [4]. The following reasons are given for an inappropriate growth of productivity in civil engineering, and as obstacles hindering improvement in this sector: segmented and insufficiently interrelated processes for scheduling, financing, design, engineering, supply, construction and maintenance, a great number of highly varied participants in the realisation of projects, insufficient use of new technologies, inadequate quality and training of labour, work in open space, susceptibility to changes, lack of efficient procedures for measuring achievements, insufficient investment in research, etc. [1].

Several authors have pointed out that inadequate scheduling may be one of significant reasons why productivity in civil engineering has not been increasing $[1,6]$. In fact, inadequate scheduling causes insufficient engagement of labour during working hours (work interruptions or work at reduced intensity). The quality of schedules is highly significant for successful implementation of projects, and a special significance is accorded to schedules which deal with work organisation and crew synchronisation on a micro level. However, the civil engineering industry still lacks an efficient and practical shortterm scheduling system that can describe in detail the flow of crews and work at that level [7]. Generally accepted scheduling techniques based on the Critical Path Method (CPM) are more appropriate for long-term scheduling than for the detailed scheduling level [8].

Civil engineering is characterized by products that are static and production forces that are dynamic, which is opposite to the situation prevailing in other branches of industry [5]. This is why positive work organisation systems applied in successful industrial branches can not simply be copied to civil engineering. Existing scheduling systems are analysed in this paper, and a new short-term scheduling system is proposed. This new system is expected to overcome the restrictions of existing approaches, and to create conditions for greater application of other industries' positive practice, which would result in a higher productivity in civil engineering. The research is limited to construction of multistorey buildings which are considered to be one of more complex situations for detail scheduling per crews.

\section{Research methodology}

It has been noted in literature and practice that some problems exist with regard to an increase in productivity in civil engineering [1-5], and as to the link between the productivity and scheduling $[1,6]$. The existing scheduling methods are analysed in the paper, their advantages and defects are studied, and comparison between individual methods is made. Possibilities for improving existing approaches to scheduling are considered and a new approach, based on scheduling per work cycles, is proposed. This new approach has been verified on construction sites of seven multi-storey buildings.

It is assumed that its use could contribute to the elimination of limitations of existing approaches to short-term scheduling, and also to the increase in productivity. Results obtained have confirmed the assumption that the use of WCBS leads to higher productivity on construction sites.

\section{Existing approaches to scheduling in civil engineering}

Usual present-day approaches to scheduling are: Last Planner System (LPS), Location Based Management (LBM), 4D modelling, and the traditional approach based on CPM.

\subsection{Last Planner System (LPS)}

LPS is a scheduling system in which higher scheduling levels are delegated to First Planners and short-term scheduling to Last Planners [10-12]. The Last Planner is the person or group accountable for production unit control, and for completion of individual assignments at the operational level [6]. In this way, the role of LPS is to provide better perception of micro conditions and restrictions, and to achieve better synchronization of work. Look-ahead schedules for a period from 4 to 6 weeks are developed within LPS and their basic function is to analyse and provide preconditions for timely realization of activities [14]. Only the activities whose preconditions have already been realized are considered in weekly schedules. Weekly schedules represent a mutual agreement regarding tasks for the next week, which are coordinated at weekly meetings [15]. However, LPS continues the tradition of CPM by not taking into account the location of activities [15].

\subsection{Location Based Management (LBM)}

Within this approach, workflows are determined. Each workflow is seen as a set of homogenous activities which reoccur at different locations and for which a separate work brigade is responsible. The flows and activities are represented in diagrams as lines in the time-space coordinate system [16,17]. Locations are divided according to levels and a corresponding location breakdown structure is determined for each project $[18,19]$. LBM contains tools for coordination of workflows during scheduling, and also an "alarm" system which warns of space and time "conflicts" of the labour during realization of works due to different progress of workflows [18]. LBM insists on the establishment of continuous workflows, which contributes to the lowering of labour costs. 
However, LBM does not deal with short-term scheduling and the day tasks system, which is why a combined application of both LPS and LBM is suggested. It is emphasized that the given hypotheses regarding improvement of productivity should be further examined [9].

\subsection{D modelling}

The $4 \mathrm{D}$ modelling is a combination of spatial data and time scheduling. The onnection is made between construction components from 3D cad models and activities from time schedules [21-25]. 4D modelling determines space-time conflicts of activities, and points to mistakes in the schedules which should be rectified prior to realization of such schedules [21,24].

The Building Information Modelling (BIM) is an integrated information model for buildings which contains, in addition to the data on building geometry and 3D elements, a number of other parameters which describe the building in greater detail (spatial relationships, specifications, characteristics of building components, formulations, quantities, etc.) [26]. BIM contains combined data needed by participants in the project, contributes to better integration of processes operated during the design and realization of works [27], and can be applied throughout the life cycle of the project [28]. The use of BIM in 4D modelling is of great help to contractors and other participants on the project, as it enables better coordination and planning of construction processes, more efficient decision making, and better implementation of such decisions [27, 29-32].

Through application of 4D modelling and simulation, the part of scheduling performed on-site could be reduced, and learning from mistakes could be avoided [33]. The same authors state that it is a challenge to find such a work schedule where crews are not in each other's way and where continuity of work is ensured. Short-term schedule visualisations are of special significance for better work organisation and understanding of schedules by their direct implementers [34].

The workflow management can be divided into macro management and micro management [21]. The macro management is related to long-term schedules and $4 \mathrm{D}$ modelling, and there the aim is to achieve harmonized workflows. The micro management is based on LPS principles, and it places emphasis on the relevance of daily scheduling [21], but does not show the way in which daily tasks and daily locations are estimated.

\subsection{Restrictions of existing approaches}

The use of LBM, LPS and 4D modelling approaches enables good quality long-term scheduling. However, main restrictions of existing approaches actually lie in the short-term scheduling i.e. in the scheduling on a micro level (daily schedules per crews) $[7,15,20,35-37]$, where the organisation of work and scheduling is delegated to foremen (Last Planners), without system rules and indicators. In practice, foremen can be subjective and unable to see what is the best solution for the overall project $[34,38]$, which can adversely affect the productivity.

Table 1 shows comparison of analysed scheduling approaches based on the existence of precisely defined procedures for managing work crews on a micro level. It can be seen that none of the existing approaches includes creation of work cycles based on location and technology, division of workflows into crew subflows, and calculation of daily scope of work. Certain approaches examine the issue of daily locations and crew synchronization on a micro level, but only on the level of mutual agreement or graphic representation, without any calculation. The main goal of this paper is to overcome the stated scheduling restrictions.

\section{New approach to short-term scheduling}

When preparing long-term schedules, acceptable results concerning continuity and harmonization of workflows are achieved by applying existing scheduling approaches. For short-term scheduling, a new approach using the Work Cycle Based Scheduling (WCBS) is proposed. With this new approach, the restrictions of existing scheduling approaches on the micro level are overcome.

Table 1. Comparison of scheduling approaches based on precisely defined procedures for managing work groups at micro level

\begin{tabular}{|c|c|c|c|c|c|c|}
\hline Approaches & Work flow & $\begin{array}{l}\text { Spatial and } \\
\text { technologi- } \\
\text { cal cycles }\end{array}$ & $\begin{array}{l}\text { Dividing } \\
\text { workflows into } \\
\text { crew subflows }\end{array}$ & $\begin{array}{c}\text { Calculation of } \\
\text { daily locations } \\
\text { per crew }\end{array}$ & $\begin{array}{c}\text { Calculation } \\
\text { of daily work } \\
\text { scope per crew }\end{array}$ & $\begin{array}{l}\text { Synchronisation } \\
\text { on a micro level }\end{array}$ \\
\hline LPS & No & No & No & No & No & $\begin{array}{l}\text { Agreement between last } \\
\text { planners }\end{array}$ \\
\hline LBM & Yes & No & No & No & No & No \\
\hline LBM + LPS & Yes & No & No & No & No & $\begin{array}{c}\text { Agreement between last } \\
\text { planners }\end{array}$ \\
\hline $\begin{array}{l}\text { 4D modelling - macro } \\
\text { and micro management }\end{array}$ & Yes & No & No & $\begin{array}{c}\text { graphic } \\
\text { representation }\end{array}$ & No & $\begin{array}{l}\text { Graphic and agreement } \\
\text { between last planners }\end{array}$ \\
\hline PCR - new approach & Yes & Yes & Yes & Yes & Yes & Yes; quantitative and graphic \\
\hline
\end{tabular}


Three hierarchical levels are proposed for long-term schedules (master schedule, phase schedule, and detail schedule). The vertical connection between schedules is achieved through an adequate schedule structure. The master schedule is defined as a set of key events (milestones) on the project. Workflows are formed at the phase schedule level. A workflow represents a technological line in a project, and is realized by a separate organizational unit work brigade. In a detail schedule, activities are created by splitting workflows into cycles which represent spatial and technological units with a set of operational assignments delegated to one work brigade (e.g. in case of a multi-storey building, cycles refer to storeys or to individual parts of one storey if it is delegated to different brigades). At the detail schedule level, a cycle represents one activity of a work brigade, while at the WCBS level it is a set of daily assignments per group in the work brigade.

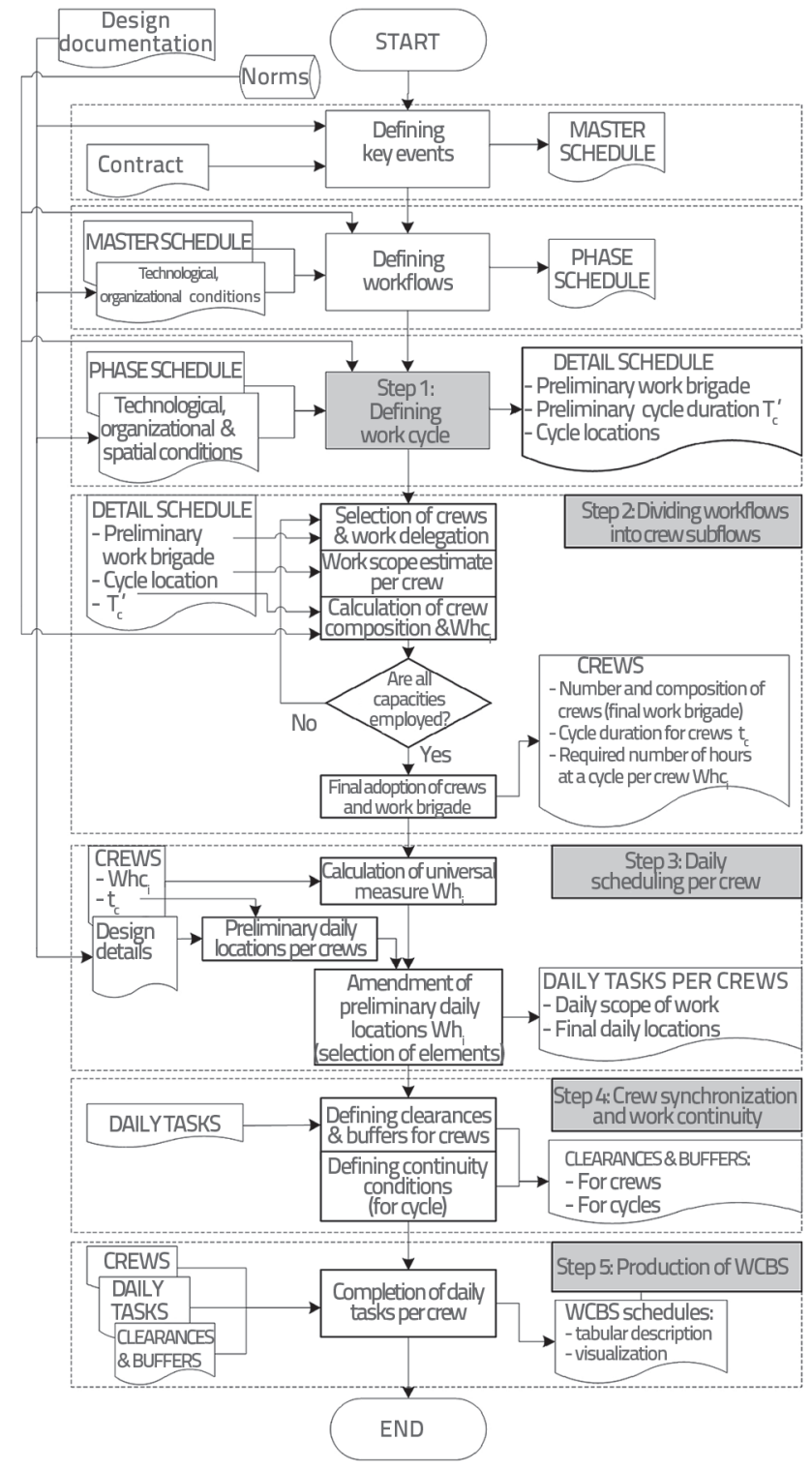

Figure 1. Steps in WCBS production and connection with long-term schedules
The following schedule implementation steps are defined in the newly proposed work cycle based scheduling (WCBS):

1. cycle definition

2. classification of workflows into subflows, and definition of crews

3. daily scheduling

4. crew synchronization and achieving continuity of work

5. preparation of time schedule for a cycle.

A process diagram with steps for the preparation of WCBS, and WCBS connections to long-term schedules, is presented in Figure 1.

\subsection{Cycle definition}

The cycle definition activity is conducted at the detail schedule preparation stage. WCBS is prepared only for different cycles (e.g. underground storeys, standard storeys, and lofts). The cycle duration $T_{c}{ }_{c}$ in the detail schedule is calculated based on the scope of work, norms, contract requirements, and restrictions. This duration is preliminary and serves as input for calculations in WCBS, after which the final duration is determined, and the detail schedule is amended where required.

\subsection{Classification of workflows into subflows and definition of crews}

Every workflow is delegated to one work brigade consisting of several crews. Subflows are created by distribution of work among crews. Crews perform the same tasks at every cycle, and so the specialization of work, being one of the main principles of industrial production, can be achieved. The work crew composition is calculated based on the associated scope of work within a cycle, norms and accepted cycle duration $t$ for work crews, which corresponds to the cycle duration in the detail schedule $T_{c}^{\prime}$. If the level of crew engagement, or the labour structure, are not at a satisfactory level, the work is redistributed among the crews with the same types of workers, and the procedure is repeated. For calculation of the crew $E_{i}$ level of engagement $U c_{i^{\prime}}$ this paper proposes the ratio of required number of work-hours $W h c_{i}$ to the accepted number of work-hours $W h k_{i}$ for a cycle. The $W h c_{i}$ value is determined according to the scope of work and norms, while the $W h k_{i}$ is based on the defined number of workers, workinghours, and $t_{c}$.

$U c_{i}=\frac{W h c_{i}}{W h k_{i}}$

Within WCBS, the level of engagement is used as a parameter for the identification and measurement of the work-hour "waste" during schedule preparation, and also during realization of works.

\subsection{Daily scheduling}

A measure for the daily scope of work must be determined before preparation of daily schedules for crews. This is followed by definition of daily locations and daily assignments. 


\subsubsection{Calculation of a universal measure for defining the daily scope of work for crews}

Considering that one crew performs a number of different work items during a cycle, the question remains how to equalize their daily assignments, and which measure should be used to realistically show the daily scope of work. The WCBS system proposes a new measure named daily total of a crew's work-hours $W h_{i}$ which represents the ratio of $W_{h} c_{i}$ (the total allocated norm hours in a cycle for a crew $E_{i}$ ) to the cycle duration $t_{c}$ for this crew.

$W h_{i}=\frac{W h c_{i}}{t_{c}}$

The above measure represents the total work-hours a particular crew should realize every day, in order to keep its productivity equal to the planned productivity.

\subsubsection{Calculation of daily locations and daily assignments per crew}

The number of daily locations complies with the cycle duration for crews, $t_{c}$. Preliminary daily locations, which have to meet the designed, technological and organisational requirements, are defined first, and then they are amended according to different concentration of work at a cycle location.

Within preliminary daily locations, elements are allocated to each crew $E_{i}$ according to their technological order of execution, until the sum of norm hours for these elements becomes equal to the daily total of work-hours $\mathrm{Wh}_{\mathrm{i}}$.

Elements selected in such a way define the daily scope of work, and the space in which they are located is the final daily location. A crew's daily assignment is determined by the daily location and the daily scope of work. In WCBS, daily locations and elements of the structure that are built each day, are marked on the floor plan of the building.

Clearly distinct one-day locations can be formed for most crews. However, multiday locations can also be formed in some special cases. Such multiday locations are characterized by a great concentration of work in a restricted space (elevator and staircase shafts), where one or more crews may be required to perform their work for several days. In such cases, micro cycles are formed. These micro cycles must be harmonized with other works within the cycle. Daily assignments for crews operating in the micro cycle are divided into elements, and the distance between the crews is ensured by dividing multiday locations into smaller technological units where crews can rotate even during a single day.

\subsection{Crew synchronization and continuity of work}

WCBS insists on harmonization of crews within each flow. This includes crew synchronization within a cycle, and a guaranteed continuity of work when moving on to the next cycle.

\subsubsection{Crew synchronization}

In order to enable synchronized work of crews in a cycle, the duration of their work, $t_{c}$ must be similar, and appropriate spacetime clearances $Z_{i}$ must be provided between the crews. These clearances may be due to the work technology used, or to the variability in shape, size and position of daily locations $\left(\mathrm{L}_{z^{\prime}}\right.$ Figure 2). Additional time buffers $\mathrm{Bf}_{i}$ between individual crews may be introduced and used in order to compensate for potential delays. Clearances result from concrete real-life conditions, while additional time buffers are defined by the planner, as necessary. Crews are introduced to a cycle in keeping with a predefined technological order. The correlation between two adjoining crews $\mathrm{E}_{\mathrm{i}}$ and $\mathrm{E}_{\mathrm{i}+1}$ can be presented as follows:

$D\left(E_{i+1}\right)=D\left(E_{i}\right)+Z_{i}+B f_{i}$

where:

$D\left(E_{i+1}\right)$ - work day for crew $E_{i+1}$

$D\left(E_{i}\right)$ - work day for crew $E_{i r}$

$Z_{i}$ - clearance between crews $E_{i}$ and $E_{i+11^{\prime}}$

$\mathrm{Bf}_{\mathrm{i}}$ - buffer between crews $\mathrm{E}_{\mathrm{i}}$ and $\mathrm{E}_{\mathrm{i}+1}$.

Work days $D\left(E_{i}\right)$ are counted from the start of work on the first cycle. The total duration of works in the cycle $T_{c}$ with $m$ crews can be shown as:

$T_{c}=t_{c}+\sum_{i=1}^{m-1}\left(Z_{i}+B f_{i}\right)$

The duration obtained in this way differs from the preliminary cycle duration $T_{c}$ ' defined in the preliminary detail schedule and, consequently, the detail schedule requires amendment.

\subsubsection{Achieving continuity of work for crews}

To ensure continuity of work, crews need to be synchronized within the cycle, and should be able to pass on to the next cycle without downtime. In order to achieve continuous movement of crews between cycles during construction of multi-storey buildings, the crew $\mathrm{E}_{\mathrm{m}}$ (which is the last one to start work within a cycle) must complete at least the works on its first daily location before the crew $\mathrm{E}_{1}$ (which is the first to start the next cycle) resumes work on the same location in the next cycle. In the example presented in Figure 2, such a connection has been established between the carpentry crew on vertical elements $T_{V}\left(E_{1}\right)$ and the concrete works crew on horizontal elements $B_{H}$ $\left(E_{5}\right)$. The above requirement may be expanded by introducing the time/space clearance $Z_{c}$ and/or buffer $B_{c}$ between two cycles. Based on this, the following continuity requirement is defined:

$D\left(E_{m}\right)+1+B f_{c}+Z_{c}=D^{\prime}\left(E_{1}\right)$

where:

$D\left(E_{m}\right)$ - work day for crew $E_{m^{\prime}}$

$D^{\prime}\left(E_{1}\right)$ - work day for crew $E_{1}$ on the next cycle. 
Since the same duration of works is accepted for all crews included in the cycle, the established rhythm is transferred from the first crew to all other crews that take part in the cycle.

\subsection{Preparation of a work schedule for a cycle}

Based on the results of previous calculations, the first planner produces the WCBS, which can be presented either as a table, as a Gantt chart, or as a visualization. For practical use, the $2 \mathrm{D}^{+}$visualization of the progress of work (combination of $2 \mathrm{D}$ drawings and time schedule) is quite practical because it can be easily understood by the workers and does not require IT knowledge. The visualization per crews shows schedules of their work on a cycle, whereas the visualization per work days shows the way in which crews have been synchronised.

A $2 \mathrm{D}^{+}$visualization of construction cycle for a typical storey of a residential building is shown in Figure 2. Five work crews are envisaged for realization of this cycle: 1) carpenters for vertical elements $T_{v^{\prime}}(2)$ steel-benders for vertical elements $A_{v^{\prime}} 3$ ) carpenters for horizontal elements $T_{H}$ 4) steel-benders for horizontal elements $A_{H^{\prime}}$ and 5) concrete workers for horizontal elements $B_{H^{\prime}}$. The floor plan of the building shows daily locations $\left(\mathrm{L}_{\mathrm{V}, i^{\prime}} \mathrm{L}_{\mathrm{H}, \mathrm{i}}\right.$ and $\left.\mathrm{L}_{\mathrm{B},}\right)$. Crews with the same daily locations are grouped together and shown on one floor plan. In addition to daily locations, work days $\left(D_{k}\right)$ are also shown for each crew, counting from the start of the first cycle. The space-time clearances between crews $\left(Z_{i}\right)$ are are equally presented.
The realization of the first cycle is of special significance for implementation of the WCBS. It can be compared to trial production in a manufacturing industry during which deficiencies should be spotted, crews trained, discrepancies eliminated, and planned production achieved. It is therefore recommended that the scheduled works be controlled on the daily basis by the first planner during the first cycle. After that, it is recommended that the daily control be conducted by foremen who control the work of crews that are under their authority. The assistant site engineer controls the work of foremen, gathers together all data on the daily basis, and is accountable for the daily checking of schedules. The first planner controls the work of the assistant site engineer, checks realization of schedules of the weekly basis or after each cycle, defines guidelines and, in case of discrepancies, proposes corrective actions.

\subsection{Amendment of long-term schedules}

Calculation results (duration, crew composition, clearances, buffers, resources, etc.) from WCBS are entered into the detail schedule, which is then recalculated. This produces realistic long-term schedules and better vertical interconnection between different levels of scheduling. In addition, favourable preconditions are created for better quality control of longterm schedules.

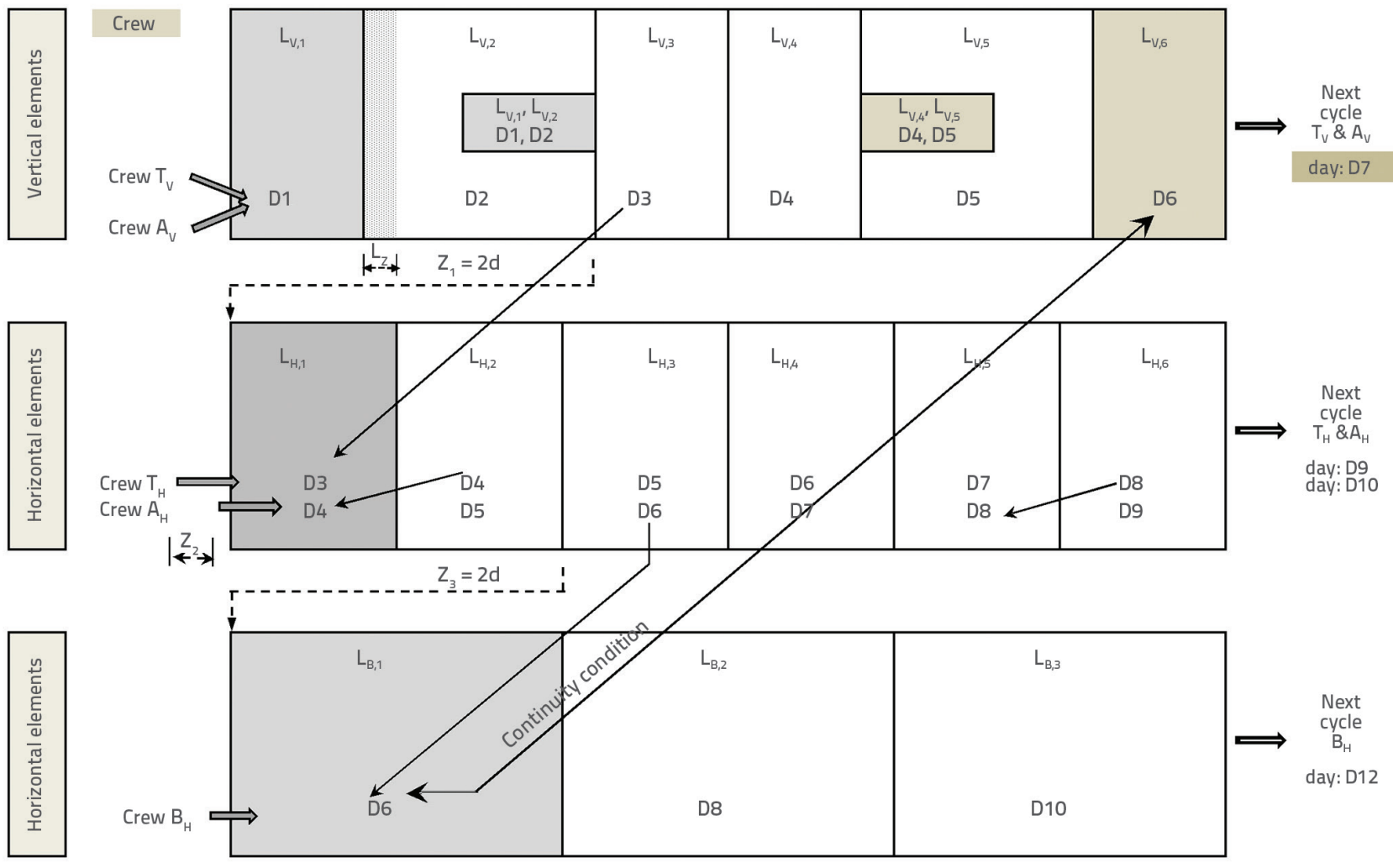

Picture 2. 2D+ visualization of WCBS for a typical residential building storey 
Table 2. Extract from WCBS for construction of vertical elements of a typical storey of building $A_{1}$

\begin{tabular}{|c|c|c|c|c|c|c|c|c|c|c|}
\hline \multicolumn{11}{|c|}{ CYCLE } \\
\hline CREWS & Activities & \multicolumn{2}{|c|}{$d_{1}$} & $\ldots$ & \multicolumn{2}{|l|}{$d_{8}$} & \multicolumn{2}{|c|}{ Required for cycle } & Whk $_{i}$ & $U c_{i}$ \\
\hline \multirow{4}{*}{$\begin{array}{c}A_{v}=3 \text { steelbenders } \\
\text { Vertical } \\
\text { elements }\end{array}$} & & $L\left(A_{v}\right)_{1}$ & $\mathrm{D}_{1}$ & & $L\left(A_{v}\right)_{8}$ & $\mathrm{D}_{8}$ & & & \multirow{4}{*}{$240 \mathrm{~h}$} & \multirow{4}{*}{0,99} \\
\hline & \multirow{2}{*}{ Pillar reinforcing } & 11 pcs & \multirow{3}{*}{$30 \mathrm{~h}$} & & 7 pcs & \multirow{3}{*}{$\begin{array}{c}27,9 \\
h\end{array}$} & 37 pcs & & & \\
\hline & & $790 \mathrm{~kg}$ & & & $480 \mathrm{~kg}$ & & $2597 \mathrm{~kg}$ & $237,9 \mathrm{~h}$ & & \\
\hline & Wall reinforcing & & & & $267 \mathrm{~kg}$ & & $3866 \mathrm{~kg}$ & & & \\
\hline \multirow{3}{*}{$\mathrm{T}_{\mathrm{v} 1}=3$ carpenters } & & $L\left(T_{V_{1}}\right)_{1}$ & $\mathrm{D}_{2}$ & & $L\left(T_{V_{1}}\right)_{8}$ & $D_{9}$ & & & \multirow{3}{*}{$240 \mathrm{~h}$} & \multirow{3}{*}{0,98} \\
\hline & Formwork (erect\&dismantle) & $23,22 \mathrm{~m}^{2}$ & \multirow{2}{*}{$30 \mathrm{~h}$} & & $18,90 \mathrm{~m}^{2}$ & \multirow{2}{*}{$\begin{array}{c}26,60 \\
h\end{array}$} & $174,69 \mathrm{~m}^{2}$ & & & \\
\hline & Concreting & $1,89 \mathrm{~m}^{3}$ & & & $2,36 \mathrm{~m}^{3}$ & & $17,46 \mathrm{~m}^{3}$ & $234,<11$ & & \\
\hline \multirow{4}{*}{$\mathrm{T}_{\mathrm{v} 2}=5$ carpenters } & & $\mathrm{L}\left(\mathrm{T}_{\mathrm{V} 2}\right)_{1}$ & $D_{2}$ & & $L\left(T_{V 2}\right)_{8}$ & $D_{9}$ & & & & \\
\hline & Formwork erection & $87,72 \mathrm{~m}^{2}$ & \multirow{3}{*}{$50 \mathrm{~h}$} & & & \multirow{3}{*}{$\begin{array}{c}48,19 \\
h\end{array}$} & $325,72 \mathrm{~m}^{2}$ & \multirow{3}{*}{$396,4 \mathrm{~h}$} & \multirow{3}{*}{$400 \mathrm{~h}$} & \multirow{3}{*}{0,99} \\
\hline & Formwork dismantling & & & & $126,80 \mathrm{~m}^{2}$ & & $325,72 \mathrm{~m}^{2}$ & & & \\
\hline & Concreting & & & & & & $32,10 \mathrm{~m}^{3}$ & & & \\
\hline
\end{tabular}

\section{WCBS application: case study}

The new approach to short-term scheduling - WCBS - was applied on a case study which includes construction of seven residential-commercial buildings with the total floor area of $78.000 \mathrm{~m}^{2}$. The buildings have one underground and 6 to 8 above-ground storeys, and their plan areas range from 900 $\mathrm{m}^{2}$ to $2.300 \mathrm{~m}^{2}$. These buildings are frame structures with elevator and staircase shafts.

Procedures presented in Section 3 were applied during preparation of WCBS. Work cycles were established for each storey. An extract from WCBS for crews building vertical elements of the building $A_{1}$ 's typical floor structure, measuring $925 \mathrm{~m}^{2}$ in area, is shown in Table 2. The following data are presented for each crew: name and designation of the crew, type and number of workers, structural elements on which works are carried out, crew activities, daily locations, daily scope of work, daily work hour total $\mathrm{Wh}_{\mathrm{i}^{\prime}}$ work days in the cycle $d_{j}$ (starting from the day on which the crew is introduced to the cycle), work day $D_{k}$ counted from the start of the first cycle, quantities of work and the required norm hours for the cycle, accepted total of crew work hours Whk $\mathrm{k}_{\mathrm{i}}$ and level of engagement $U c_{i}$.

For multiday locations (staircase and elevator shafts) on building $A_{1}$, micro cycles are elaborated and incorporated into the cycle. For the carpentry crew $T_{\mathrm{V}^{\prime}}$ the full daily employment is achieved through micro cycles (carpenters perform formwork and concreting works) and for the steel-bender crew $A_{v}$ through the whole cycle (Figure 3).

The WCBS is prepared in such a way that the number of workers per crew is constant, all crews are continuously employed at a constant level of work load, and with a high level of engagement (Table 2). This provides preconditions for maximization of productivity and thus short-term scheduling

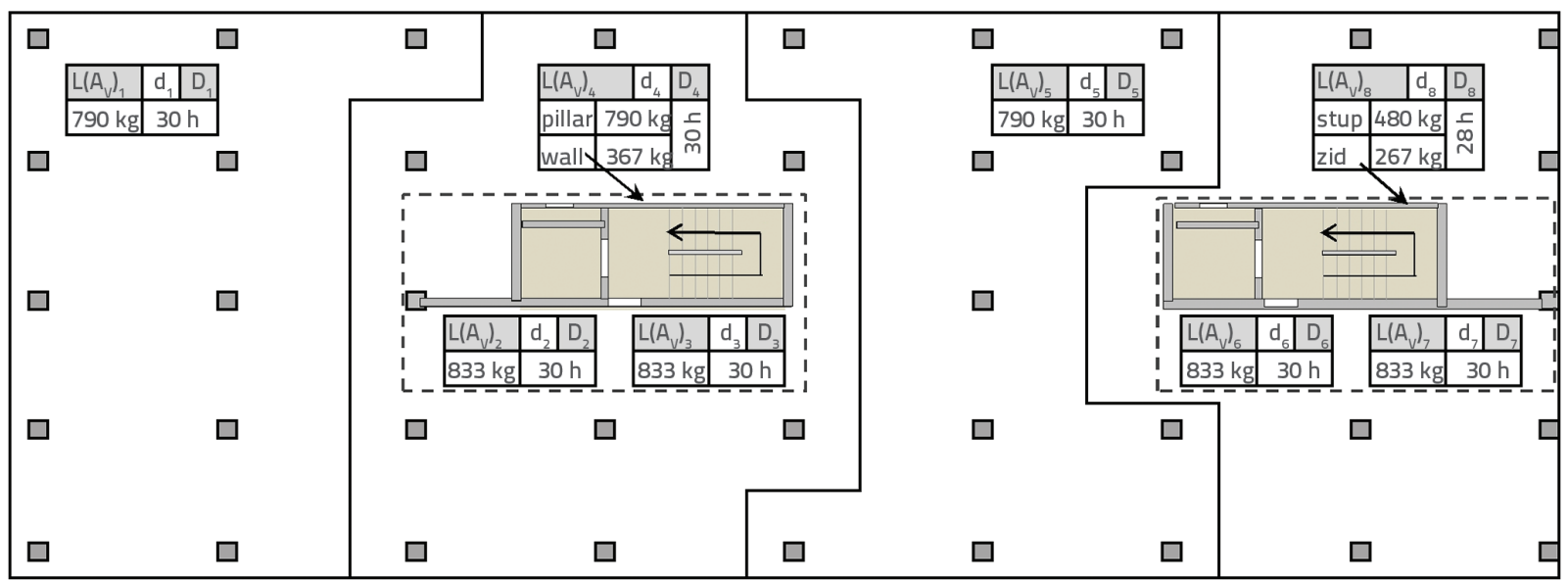

Figure 3. 2D+ visualization of WCBS for steel-bender crew $A_{v}$ during construction of a typical storey of building $A_{1}$ 
Table 3. Results obtained by measuring actual productivity

\begin{tabular}{|c|c|c|c|c|c|c|c|c|c|c|c|c|}
\hline & \multirow{2}{*}{ Structures } & \multicolumn{8}{|c|}{ IP - productivity index per cycle } & \multirow{2}{*}{$\begin{array}{c}\mathrm{PI}_{\text {average }} \\
\text { traditional } \\
\text { approach }\end{array}$} & \multirow{2}{*}{$\begin{array}{c}\mathrm{PI}_{\text {average }} \text { WCBS } \\
\text { applied }\end{array}$} & \multirow{2}{*}{ Difference } \\
\hline & & $C_{1}$ & $C_{2}$ & $C_{3}$ & $\mathrm{C}_{4}$ & $C_{5}$ & $C_{6}$ & $C_{7}$ & $C_{8}$ & & & \\
\hline \multicolumn{13}{|c|}{ 1) WCBS of cycle $C_{2}$ or $C_{3}$} \\
\hline & Building $A_{1}$ & 0,70 & 0,72 & 0,91 & 1,02 & 1,03 & 1,03 & & & 0,71 & 1,00 & 0,29 \\
\hline & Building $A_{2}$ & 0,72 & 0,74 & 0,97 & 1,01 & 1,01 & 1,03 & & & 0,73 & 1,01 & 0,28 \\
\hline & Building $\mathrm{B}_{1}$ & 0,65 & 0,67 & 0,93 & 1,02 & 1,02 & 1,05 & & & 0,66 & 1,01 & 0,35 \\
\hline & Building $\mathrm{B}_{2}$ & 0,48 & 0,65 & 0,67 & 0,72 & 0,7 & 0,72 & & & 0,48 & 0,69 & 0,21 \\
\hline & Building D & 0,75 & 0,95 & 1,01 & 1,03 & 1,03 & 1,02 & & & 0,75 & 1,01 & 0,26 \\
\hline \multicolumn{13}{|c|}{ II) WCBS \& trained crews } \\
\hline$>$ & Building $F_{1}$ & 0,95 & 1,01 & 1,09 & 1,12 & 1,1 & 1,12 & 1,09 & 1,12 & & 1,11 & \\
\hline$>$ & Building $F_{2}$ & 0,96 & 1,02 & 1,05 & 1,05 & 1,1 & 1,08 & 1,08 & 1,07 & & 1,07 & \\
\hline
\end{tabular}

is done systematically, which is not possible if other scheduling approaches are applied. The $2 \mathrm{D}^{+}$visualization of WCBS for the steel-bender crew $A_{v}$ is shown in Figure 3.

Since one of the WCBS's basic goals is to increase productivity, the effects of applying WCBS scheduling approach were analysed by making comparison between the actual productivity and planned productivity. The productivity index (PI) was accepted for measuring productivity. PI is the ratio between the work hours allocated and the work hours actually spent [39]:

$P I=\frac{\sum_{j=1}^{m} \sum_{i=1}^{k_{j}}\left(q_{i, j}{ }^{*} n s_{i, j}\right)}{\sum_{j=1}^{m} o s_{j}}$

where:

$\mathrm{q}_{\mathrm{i}, \mathrm{j}} \quad$ - executed amount of work for activity "i" performed by crew $E_{j}$

$n_{i, j} \quad$ - time norm for activity "i" performed by crew $E_{j^{\prime}}$

os $_{j} \quad$ - actual hours of crew $E_{j}$,

$k_{j} \quad$ - number of activities performed by crew $E_{j \prime}$

m - number of crews.

If $\mathrm{Pl}$ is greater than 1, the actual productivity is greater than the planned productivity. Actual productivity measurement results are shown in Table 3.

The top part of Table 3 shows buildings in which some storeys were built using the traditional scheduling approach (shaded cycles), while the remaining ones were built using the WCBS (not shaded cycles). The comparison of average productivity results shows that the productivity is much greater when the WCBS is used (PI increased by 0.21 to 0.35 ).

In six analysed cases, the use of WCBS resulted in an average productivity that is equal to or greater than the planned productivity initially used in preparation of the contract tender. The exception was the contractor for the building
B2 who showed improvement, but failed to achieve planned performance due to inadequate quality and structure of his labour. However, this helped the contractor to see real abilities and limitations of his crews and, consequently, to make appropriate strategic decisions.

The second part of Table 3 shows buildings $F_{1}$ and $F_{2^{\prime}}$ which were constructed by crews trained in the use of the WCBS. An average productivity achieved by these crews is greater than that of the crews that have been using the WCBS for the first time.

WCBS schedules used for construction of buildings in the case study, proved to be clear to the workers (especially $2 \mathrm{D}^{+}$ visualizations) and as such were quickly adopted. By the end of cycle one, crews were achieving almost maximum daily performance levels. Scheduling was much easier due to repetition of cycles and the fact that there was no need for more complex rescheduling of long-term plans. Due to the WCBS data structure, daily achievements were easily measured, which additionally motivated the crews.

\section{Conclusion}

When existing scheduling approaches are used, a good performance during construction is greatly dependant on personal qualities and commitment of planners and foremen. The proposed new approach to short-term scheduling, named WCBS, is a systematic approach with rules for preparation of short-term schedules, and with indicators for calculation of key parameters. This enables quantification, reproduction, and comparison of short time scheduling, which reduces subjectivity and dependence on the quality of individuals, and increases usability of these plans.

The WCBS can positively influence greater application of industrial manufacturing principles during realization of construction projects, which is manifested through specialization of work, establishment of cycles, preparation 
of daily schedules, control of daily performance, and trial production at the first cycle. This approach may positively influence the level of performance on construction projects.

The WCBS is based on parameters that are "designed" for crews on the daily level. Such parameters include: level of engagement, different concentration of work in space, spacetime clearances between crews, preconditions for achieving continuity of work and synchronization between crews, buffers between crews for eliminating delays, etc. In this way, the quality of plans can be improved, and conditions can be created for a more efficient control of their implementation. WCBS is compatible with the existing scheduling approaches, and represents their further development and extension, as it enables builders to overcome limitations of existing approaches with regard to micro level scheduling and schedule preparation processes.
The application of WCBS is shown on the case study involving construction of seven multi-storey building structures. The results show that the WCBS can be successfully applied for short time scheduling. When WCBS is used, a significant increase in on-site productivity, and maximum performance of crews, can be achieved in a short time. In the analyzed cases, on the same buildings, and with the same contractor's labour force, the use of the WCBS results in an increase of the productivity index PI, which increased for 0.21 to 0.35 , compared to PI achieved on the storeys on which the traditional approach was used.

The proposed WCBS approach to short term scheduling has been applied during construction of reinforced-concrete structures in the sphere of building construction. It is assumed that the logic of the WCBS approach can also be used, with some modifications, on other kinds of structures and for other works, which is to be additionally examined in further research.

\section{REFERENCES}

[1] Committee on Advancing the Competitiveness and Productivity of the U.S. Construction Industry, National Research Council: Advancing the Competitiveness and Efficiency of the U.S. Construction Industry, National Academies Press, Washington, 2009.

[2] Teicholz, P.: Labor productivity declines in the construction industry: causes and remedies, AECbytes Viewpoint, Issue 4, 2004.

[3] Triplett, J., Bosworth, B.: Productivity in the U.S. Services Sector: New Sources of Economic Growth. Brookings Institution Press, Washington, 2004.

[4] Harrison, P.: Can Measurement Error Explain the Weakness of Productivity Growth in the Canadian Construction Industry? CSLS Research Report, No. 2007-01, 2007.

[5] Pekuri, A., Haapasalo, H., Herrala, M.: Productivity and Performance Management - Managerial Practices in the Construction Industry, International Journal of Performance Measurement, Vol. 1, pp. 39-58, 2011

[6] Koskenvesa, A., Koskela, L., Tolonen, T., Sahlstedt, S.: Waste and labor productivity in production planning case finnish construction industry, Proceedings IGLC-18, Technion, Haifa, Israel, pp. 477-486, 2010.

[7] Brodetskaia, I., Sacksr R. and Shapira, A.: A workflow model for systems and interior finishing works in building construction, Construction Management and Economics, 29, pp. 1209-1227, 2011.

[8] Yu, J.H., Lee, H.S., Kim, S.K., Kim, C.D., Suh, S.W., Kim, J.H.: Planning and monitoring the tact of work flow, Proceedings of the 21st ISARC, Jeju, South Korea, 2004.

[9] Katavić, M.; Bošković, D.: Studij poslovnog upravljanja za hrvatske graditelje, Gradevinar 59 (2007) 12, str. 1073-1080

[10] Ballard, G.: The Last Planner System of production control, PhD thesis, University of Birmingham, Birmingham, UK, 2000.
[11] Hamzeh, F., Bergsrom, E.: The Lean Transformation: A Framework for Successful Implementation of the Last Planner System in Construction, ASC Proceedings of the 46th Annual International Conference Hosted by Wentworth Institute of Technology, Boston, Massachusetts, 2010.

[12] Hamzeh, F., Ballard, G., Tommelein I.: Rethinking Lookahead Planning to Optimize Construction Workflow, Lean Construction Journal, pp. 15-34, 2012.

[13] Ballard, G.: The Last Planner, Spring Conference of the Northern California Construction Institute, Monterey, 1994.

[14] Ballard, G.: Lookahead Planning: The Missing Link in Production Control, Proc. 5th Annual Conf. Int'l. Group for Lean Constr., Gold Coast, Australia, pp. 1-13., 1997

[15] Koskela, L., Stratton, R., Koskenvesa, A.: Last planner and critical chain in construction management: comparative analysis, Proceedings IGLC-18, Technion, Haifa, Israel, pp.538-547, 2010.

[16] Kenley R., Seppanen, O.: Location-based management of construction projects: part of a new typolo gy for project scheduling methodologies, Proceedings of the 2009 Winter Simulation Conference, pp. 2563-2570, 2009.

[17] Lumsden, P.: The line of balance method, Pergamon Press, London, U.K., 1968

[18] Seppanen, O.: Empirical research on the success of production control in building construction projects, PhD dissertation, Faculty of Engineering and Architecture, Helsinki University of Technology, 2009.

[19] Kenley, R., Seppänen, O.: Location-Based Management for Construction Planning, Scheduling and Control, Spon Press London and New York, 2010.

[20] Seppanen, O., Ballard, G., Pesonen, S.: The Combination of Last Planner System and Location-Based Management System, Lean Construction Journal, pp 43-54, 2010. 
[21] Jongeling, R.: A Process Model for Work-Flow Management in Construction, Doctoral thesis, Luleå University of Technology Department of Civil and Environmental Engineering Division of Structural Engineering, 2006.

[22] Koo, B., Fischer, M.: Feasibility Study of 4D CAD in Commercial Construction, Journal of Construction Engineering and Management, 126(4), pp. 251-260, 2000.

[23] Park, J., Kim, B., Kim, C., Kim, H.: 3D/4D CAD Applicability for Life-Cycle Facility Management, Journal of computing in civil engineering, march/april 2011, pp. 129-138.

[24] Ashwin, M., Rahul, K., Charudatta, M.: An evaluation of the applicability of 4D CAD on construction projects, Automation in Construction, Vol. 19, pp. 148-159, 2010.

[25] Chau, K., Anson M., Zhang, J.: Implementation of Visualization as Planning and Scheduling Tool in Construction, Building and Environment, Vol. 38, No. 5, pp. 713-719, 2003.

[26] Wikipedia - Building information modeling, http://en.wikipedia. org/wiki/Building_Information_Modeling\#Definition, 12.6.2013.

[27] Eastman, C., Teicholz, P., Sacks, R., Liston, K.: BIM Handbook: A Guide to Building Information Modelling for Owners, Managers, Designers, Engineers and Contractors, Canada: John Wiley and Sons, 2011.

[28] Lee, G., Sacks, R., Eastman, C.: Specifying parametric building object behavior (BOB) for a building information modeling system, Automation in Construction, 15(6), pp. 758-776, 2006.

[29] Weygant, R.: BIM Content Development: Standards, Strategies, and Best Practices, New Jersey: John Wiley and Sons, 2011.

[30] Succar, B.: Building Information Modelling framework: A Research and Delivery Foundation for Industry Stakeholders., Automation in Construction, 18 (3), pp. 357-375. 2009.
[31] Hardin, B.: BIM and Construction Management Proven Tools, Methods, and Workflows, Indiana: Wiley Publishing, 2009.

[32] Wakefield, R., Aranda, G., Fraser, J., Chevez, A, Crawford, J., Kumar, A., Froese, T., Gard, S., Nielsen, D., Betts, M., Smit, D.: Business Drivers for Building Information Modelling, Cooperative Research Centre, Construction Innovation, Australia, Brisbane, 2007.

[33] Norberg, H., Jongeling, R., Olofsson, T.: Planning for cast-inplace concrete construction using 4D CAD models and Line-ofBalance scheduling, Proceedings of the World IT Conference for Design and Construction, INCITE-ITCED 2006, pp. 403-414, 2006.

[34] Marinković, D.: Model za ocenu i kontrolu uspešnosti poslovanja malih i srednjih gradevinskoh preduzeća, doktorska disertacija, Gradevinski fakultet Univerziteta u Beogradu, 2008. (in Serbian)

[35] Kenley, R.: Project micromanagement: practical site planning and management of work-flow, 12th Conference of the International Group for Lean Construction, Helsingor, Denmark, 2004.

[36] Jongeling, R., Olofsson, T.: A method for planning of work-flow by combined use of location-based scheduling and 4D CAD, Automation in Construction, 16 (2007), pp. 189-198.

[37] Hamzeh, F.: Improving Construction Workflow - The Role of Production Planning and Control, PhD Dissertation, University of California at Berkeley, Berkeley, CA, 2009.

[38] Stojadinović, Z.: Sistem upravljanja projektima izgradnje stambeno-poslovnih gradevina na bazi integracije procesa projektovanja i građenja, doktorska disertacija, Gradevinski fakultet, Beograd, 2007. (in Serbian)

[39] Orczyk, J.: Progress Measurement and Earned Value (Chapter 14), Skills \& Knowledge of Cost Engineering, 5th Edition, AACE International, ed. S. Amos, USA, pp. 14.1-14.6, 2004. 